\title{
INVENTORY LABORATORIUM JASA BOGA DI SMK WILAYAH MAWITAN JAWA TIMUR
}

\author{
Samar \\ SMKN 4 Madiun \\ densamar@yahoo.co.id \\ Endang Mulyatiningsih \\ Program Pascasarjana Universitas Negeri Yogyakarta \\ ememulya63@gmail.com
}

\begin{abstract}
Abstrak
Penelitian ini bertujuan untuk mendapatkan hasil inventory Laboratorium Jasa Boga di SMK wilayah Mawitan Jawa Timur. Jenis penelitian ini adalah deskriptif kuantitif. Sumber data penelitian ini adalah laboratorium jasa boga di SMK wilayah Mawitan (Madiun, Ngawi dan Magetan). Teknik pengumpulan data yang digunakan adalah teknik observasi, instrumen check list, menggunakan lembar check list, validitas instrumen menggunakan expert justment, reliabilitasnya menggunakan interobserver. Teknik analisis data menggunakan deskriptif kuantitatif. Hasil penelitian menunjukkan bahwa: (1) Kualitas Ruang Praktik Dapur Latih semua sesuai standar spesifikasi dan mayoritas sangat layak (86\%); (2) Kualitas Ruang Praktik Tata Hidang sangat layak pada tiga sekolah (47\%), belum memiliki ruang praktik Tata Hidang pada empat sekolah (53\%); (3) Kualitas Perabot dapur latih sangat layak (86\%), kualitas layak (14\%); (4) Kualitas Peralatan Dapur Latih sangat layak (57\%), kuallitas layak (29\%) dan kualitas tidak layak14\%; (5) Kualitas Perabot Tata Hidang 29\% tidaklayak, 57\% layak dan 14\% sangat layak; (6) Kualitas Peralatan Tata Hidang, 14\% tidak layak, 57\% layak, 29\% sangat layak.
\end{abstract}

Kata Kunci: Laboratorium Jasa Boga, dapur latih SMK.

\section{THE INVENTORY FOOD SERVICE IN VOCASIONAL SCHOOL LABORATORY IN MAWITAN EAST JAVA}

\begin{abstract}
This study aims to get the inventory of food service vocational school laboratory in Mawitan East Java. This research was a descriptive quantitative. The data source of this research was the laboratory of food service of Vocational School in Mawitan region (Madiun, Ngawi and Magetan). The data were collected through observation, with instrument check list, made use of instrument check list, validity instrument made use of expert justment, reliability made use of interobserver. The data were analyzed using the descriptive quantitative. The results of the study are as follow: (1) The quality ofkicthen workshopwas appropriate with spesification standards and majority were very proper (86\%); (2) The qualityof Food and Beverage Servicewas very properin the three schools (47\%), four school (53\%) did not have food and beverage serviceyet; (3) The quality of the kitchenworkshop furnitureswas very proper (86\%), proper (14\%); (4) The qualityof kicthen workshop equipment was very proper (57\%), proper (29\%) and unproper 14\%; (5) The qualityof food and beverage service furnitureswas unproper $29 \%$, proper $57 \%$ and very proper $14 \%$; (6) The qualityof food and beverage service equipments wasunproper $14 \%$,proper $57 \%$,very proper $29 \%$.
\end{abstract}

Keywords: Food Service Laboratory, kitchen workshop in Vocasional School

\section{PENDAHULUAN}

Laboratorium merupakan sarana prasarana yang sangat penting dalam proses pembelajaran di Sekolah Menengah Kejuruan
(SMK). Laboratorium SMK yang ideal diharapkan dapat menjadi tempat berlatih atau mensimulasikan pekerjaan yang identik dengan pekerjaan yang terdapat di dunia usaha. 
Menurut Prosser dalam Sudira, P. (2012), proses pembelajaran di SMK akan efektif jika: (1) tempat pembelajaran peserta didik merupakan replika lingkungan dimana nanti akan bekerja; (2) penguasaan kompetensi dalam bentuk tugas-tugas latihan dilakukan dengan cara, alat, dan mesin yang ada di tempat kerja; (3) kebiasaan kerja dan berpikir yang benar diulang sehingga sesuai dengan keperluan kerja nantinya. Keberadaan laboratorium praktik di SMK sedapat mungkin tersedia dengan sarana prasarana yang memenuhi standar dan fasilitas peralatan praktik yang memadai, sesuai dengan yang ada di industri. Fasilitas peralatan praktik di sekolah yang kondisinya sama dengan yang di gunakan di dunia usaha dan dunia industri membuat proses pembelajaran praktik di sekolah dapat berjalan dan berhasil optimal. Para siswa yang memiliki kebiasaan kerja seperti di industri diharapkan setelah lulus memiliki kemampuan yang sesuai dengan standar industri.

Praktik kerja di laboratorium dapat melatih peserta didik SMK untuk bekerja dan secara otomatis dapat memberi bekal keterampilan untuk hidup mandiri. Laboratorium merupakan salah satu sarana dari pendidikan teknik dan kejuruan yang berfungsi sebagai tempat untuk praktik melatih dan mengembangkan keterampilan psikomotorik seseorang yang akan mendalami suatu keterampilan tertentu. Kegiatan praktik merupakan proses pembelajaran dalam rangka menanamkan kompetensi, kegiatannya dilakukan dengan mengkondisikan pada kegiatan sebenarnya atau yang konkrit. Oleh karena itu dibutuhkan suatu fasilitas praktik atau laboratorium atau bengkel atau dapur latih yang memadai.

Peraturan Pemerintah Nomor 19 Tahun 2006 tentang SNP, Pasal 26 ayat 3 yaitu "Standar kompetensi lulusan pada satuan pendidikan menengah kejuruan bertujuan untuk meningkatkan kecerdasan, pengetahuan, kepribadian, akhlak mulia, serta keterampilan untuk hidup mandiri dan mengikuti pendidikan lebih lanjut sesuai dengan kejuruannya. Tujuan tersebut kemudian dirumuskan dalam lampiran Permendiknas Nomor 23 Tahun 2006 tentang Standar Kompetensi Lulusan (SKL) yang dituangkan dalam 23 item. Kedua peraturan tersebut menuntut penyelenggaraan pendidikan di SMK harus mampu membekali siswa untuk memasuki dunia kerja.

Proses pembelajaran di SMK berprinsip pada pembelajaran berbasis kompetensi yaitu pembelajaran yang berorientasi pada hasil kerja yang terstandar (outcome-based education). Lulusan SMK diharapkan memperoleh kompetensi yaitu kemampuan yang dibangun dari pengetahuan, sikap dan keterampilan produktif sesuai dengan bidang keahliannya. Kompetensi ini diharapkan membekali siswa untuk bekerja di dunia usaha dan dunia industri maupun bekerja mandiri. Untuk melatih keterampilan yang mengarah kepada kompetensi kerja diperlukan tempat belajar yang memiliki sarana prasarana dan fasilitas peralatan yang sesuai dengan yang ada di dunia kerja.

Permendiknas Nomor 40 Tahun 2008 tentang Standar Sarana dan Prasarana untuk Sekolah Menengah Kejuruan/Madrasah Aliyah Kejuruan (SMK/MAK). Sekolah diharapkan memiliki sarana dan prasarana yang sesuai dengan standar tersebut supaya kegiatan praktik di sekolah berjalan efektif.

Standar sarana prasarana untuk Program Studi Keahlian Tata Boga Kompetensi Keahlian Jasa Boga minimal memiliki laboratorium praktik pengolahan makanan dan laboratorium praktik pelayanan Restoran. Masing-masing laboratorium dilengkapi dengan fasilitas peralatan praktik yang jumlahnya sesuai dengan kebutuhan yang diperlukan siswa di setiap rombongan belajar.

Wilayah Mawitan adalah singkatan dari wilayah Madiun, Ngawi dan Magetan yang berada di Jawa Timur bagian barat. Jadi SMK wilayah Mawitan maksudnya adalah Sekolah Menengah Kejuruan Negeri (SMKN) yang memiliki Kompetensi Keahlian (KK) Jasa Boga yang ada di Kota Madiun, Kabupaten Madiun, Kabupaten Ngawi dan Kabupaten Magetan yang berjumlah 7 sekolah, yaitu SMKN 4 Kota Madiun, SMKN 1 Wonoasri Kabupaten Madiun, di Kabupaten Magetan terdapat 4 sekolah, yakni SMKN 2 Magetan, SMKN 1 Poncol, SMKN Takeran dan SMKN Kartoharjo, SMKN 1 Geneng, Kabupaten Ngawi. 
Hasil pengamatan pra survei di beberapa SMK wilayah Mawitan ternyata sarana prasarana dan fasilitas peralatan praktik yang tersedia rata-rata masih belum memenuhi standar. Laboratorium yang dimiliki oleh sekolah memiliki luas dan kapasitas terbatas, jumlah dan jenis fasilitas peralatan yang dimiliki relatif minim (terlampir). Sarana prasarana dan fasilitas peralatan praktik yang terbatas mengakibatkan pendidikan dan pelatihan (diklat) dasar kompetensi kejuruan tidak dapat diajarkan sesuai standar kompetensi kerja yang ditetapkan padahal pendidikan kejuruan di tingkat menengah berfungsi menyiapkan siswa untuk masuk kesuatu pekerjaan. Sarana prasarana dan fasilitas peralatan praktik yang terbatas juga berakibat pada lingkungan tempat kerja siswa tidak tercipta sebagai replika dimana siswa nantinya akan bekerja. Guru produktif sering mengalami kendala dalam melakukan pembelajaran praktik. Untuk mengatasi kendala tersebut, guru produktif dituntut kreatif memilih strategi yang tepat agar kompetensi siswa tetap dapat tercapai.

Jika laboratorium SMK tidak memenuhi standar, maka keterampilan yang diajarkan juga kurang memenuhi standar. Untuk mendalami lebih jauh tentang kondisi laboratorium tersebut maka perlu dilakukan studi tentang "Inventory Laboratorium Jasa Boga di SMK wilayah Mawitan".

Tujuan penelitian adalah untuk: (1) Memperoleh gambaran kelayakan ruang praktik dapur latih di SMK wilayah Mawitan Jawa Timur; (2) Memperoleh gambaran kelayakan ruang praktik tata hidang di SMK wilayah Mawitan Jawa Timur; (3) Memperoleh gambaran kelayakan perabot dapur latih di SMK wilayah Mawitan Jawa Timur; (4) Memperoleh gambaran kelayakan peralatan dapur latih di SMK wilayah Mawitan Jawa Timur; (5) Memperoleh gambaran kelayakan perabot tata hidang di SMK wilayah Mawitan Jawa Timur; (6) Memperoleh gambaran kelayakan peralatan tata hidang di SMK wilayah Mawitan Jawa Timur

Menurut (Kamus Besar Bahasa Indonesia, 2007: 646) "kelayakan adalah "1 perihal layak (patut, pantas); kepantasan; kepatutan; 2 perihal yang dapat (pantas, patut) dikerjakan".
"Pantas, 1 Patut; layak ... 2 sesusi; sepadan" (Kamus Besar Bahasa Indonesia, 2007: 826). Kelayakan laboratorium adalah kesesuaian spesifikasi, jumlah dan kondisi sarana prasarana laboratorium dengan standar kelayakan yang telah ditentukan.

\section{Sekolah Menengah Kejuruan.}

Pendidikan menengah di Indonesia mengacu pada 8 (delapan) Standar Nasional Pendidikan yang dikembangkan oleh Badan Standar Nasional Pendidikan (BSNP), yang pemberlakuannya disahkan oleh Depdiknas RI melalui Undang-Undang Nomor 20 Tahun 2003 tentang. Standar Nasional Pendidikan mempunyai kriteria minimum yang semestinya dipenuhi oleh penyelenggara pendidikan. Standar tersebut meliputi: (1) Standar isi; (2) Standar proses; (3) Standar kompetensi lulusan; (4) Standar pendidikan dan tenaga pendidikan; (5) Standar sarana dan prasarana; (6) Standar pengelolaan; (7) Standar pembiayaan pendidikan, dan (8) Standar penilaian pendidikan.

Sebagaimana tercantum dalam PP Nomor 19 Tahun 2005 Tentang Standar Nasional Pendidikan BAB VII Standar Sarana dan Prasarana Pasal 42, Ayat 2:

Setiap satuan pendidikan wajib memiliki prasarana yang meliputi lahan, ruang kelas, ruang pimpinan satuan pendidikan, ruang pendidik, ruang tata usaha, ruang perpustakaan, ruang laboratorium, ruang bengkel kerja, ruang unit produksi, ruang kantin, instalasi daya dan jasa, tempat berolahraga, tempat beribadah, tempat bermain, tempat berkreasi, dan ruang/ tempat lain yang diperlukan untuk menunjang proses pembelajaran yang teratur dan berkelanjutan.

Sekolah Menengah Kejuruan berorientasi untuk menghasilkan lulusan yang siap kerja, mandiri dan melanjutkan ke pendidikan yang lebih tinggi. SMK bukan pendidikan terminal tetapi justru pendidikan yang memberi kesempatan kepada para lulusannya menjadi generasi yang memiliki kesempatan yang lebih luas dan luwes/fleksibel. Lulusan SMK yang tidak dapat melanjutkan ke perguruan tinggi dapat langsung bekerja untuk memenuhi 
kebutuhan ekonomi. Siswa SMK telah di bekali sejumlah kompetensi yang dapat menjadi modal awal dalam merancang karier.

Menurut (Pavlova, 2009: p 7):

Traditionally, direct preparation for work was the main goal of vocational education. It was perceived as providing specific training that was reproductive and based on teachers'instruction, with the intention to develop understanding of a particular industry, comprising the specific skills or tricks of the trade. Students' motivation was seen to be engendered by the economic benefits to them, in the future.

Maksudnya bahwa secara umum tujuan utama pendidikan kejuruan adalah untuk siap kerja. Guru memberikan pelatihan khusus berdasarkan reproduksi industri, yang terdiri dari keterampilan atau langkah-langkah sesuai dengan perusahaan tertentu. Motivasi belajar siswa akan terlihat yang ditimbulkan oleh manfaat ekonomi kepada mereka di masa depan.

Menurut Kurikulum SMA/SMK tahun 2013 struktur kurikulum terdiri atas Kelompok Mata pelajaran wajib A dengan porsi 17 jam pelajaran/minggu, Mata pelajaran wajib $B$ dengan porsi 7 jam pelajaran/minggu, dan Mata pelajaran Peminatan $C$ dengan porsi 24 jam pelajaran/ minggu. Pada SMA/SMK Mata pelajaran Kelompok Peminatan (C) tediri atas a) Kelompok Mata Pelajaran Dasar Bidang Keahlian (C1); Kelompok Mata Pelajaran Dasar Program Keahlian (C2); Kelompok Mata Pelajaran Dasar Paket Keahlian (C3); Jika dilihat dari persentase jumlah teori dan praktik pada kurikulum 2013 yang mata pelajaran wajib A dan B (teori) sebesar 24 jam pelajaran/minggu atau $50 \%$ sedangkan mata pelajaran peminatan $C$ (praktik) sebesar 24 jam pelajaran/ minggu atau 50\%. Jika dicermati secara seksama proses pembelajaran di SMK di kedua kurikulum tersebut menuntut adanya fasilitas praktik yang komplit dan memadai, karena fasilits praktik yang lengkap akan menunjang keberhasilan pembelajaran praktik di laboratorium.

\section{Laboratorium}

Laboratorium diartikan sebagai suatu tempat dilakukannya percobaan dan penelitian yang berfungsi untuk melakukan pembuktian suatu teori dalam rangka pengembangan kognitif. Laboratorium Jasa Boga merupakan sarana prasarana atau ruang, perabot dan peralatan yang berfungsi untuk mengembangkan keterampilan produktif dan juga di gunakan untuk melakukan percobaan yang terkait dengan makanan, (Misalnya: percobaan resep masakan). Dalam Kamus Besar Bahasa Indonesia dijelaskan: "laboratorium suatu tempat atau kamar tertentu dsb yang dilengkapi dgn peralatan untuk mengadakan percobaan (penyelidikan dsb)". Rahayuningsih dan Dwiyanto, 2005: p 1 menjelaskan bahwa: "Laboratorium adalah suatu sarana atau gedung yang dirancang khusus untuk melaksanakan pengukuran, penetapan, dan pengujian untuk keperluan penelitian ilmiah dan praktik pembelajaran".

Persyaratan Laboratorium, sebagaimana dijelaskan (Lucia M. Berte, MA, MT: 2007, p 780):

The laboratory should establish selection criteria for each piece of equipment it needs to acquire, and should determine which vendors can meet those criteria. Before equipment is selected, the laboratory needs to verify that the laboratory's physical facility can meet the equipment's needs for space and load bearing; electricity, ventilation, humidity, and temperature; water type and quality; and any other special requirements.

After arrival, and before use, each piece of equipment needs to be installed and initially verified as meeting the manufacturer's stated performance characteristics. After the onset of the actual testing, the equipment must also be verified as functioning as intended in the actual work processes in which it is used. Laboratory schedules and procedures that follow manufacturer's instructions are required for ongoing preventive maintenance, calibrations, and calibration verification; performance records provide objective evidence of outcomes of these required activ- 
ities. Troubleshooting, service, and repair records are also required. Reconstruction of the history of each piece of equipment from acquisition to decommission should be traceable from the equipment records.

Dapat diartikan bahwa Laboratorium harus menentukan kriteria untuk masingmasing peralatan yang dibutuhkan, dan harus menentukan vendor yang dapat memenuhi kriteria tersebut. Sebelum peralatan dipilih, laboratorium perlu memverifikasi bahwa fasilitas fisik laboratorium dapat memenuhi kebutuhan peralatan untuk ruang dan beban nyata; listrik, ventilasi, kelembaban, dan suhu; jenis dan kelayakan air; dan persyaratan khusus lainnya.

\section{Ruang Praktik Dapur Latih.}

Fungsi dan Peranan Dapur Latih/Dapur Produksi (Kitchen Product).

Di hotel besar, bagian atau departemen yang bertugas menyediakan layanan makanan dan minuman disebut "Food and Beverage Departement". Bagian ini terdiri dari "Kitchen" yaitu bertugas memproduksi makanan, "Restaurant" sebagai tempat menyajikan makanan, "Bar" sebagai tempat menyajikan minuman. Apabila hotel yang memiliki banyak restoran maka hotel tersebut akan memiliki dapur utama (main kitchen) sebagai tempat pengolahan awal seperti pemotongan daging, unggas, ikan dan membuat saus-saus dasar dan mengolah makanan dalam jumlah banyak. (Sudira, 2004: pp 2-3).

Standar ruang dapur latih, Dalam (Lampiran Permendiknas Nomor 40, Tahun 2008: p 145) di nyatakan bahwa "rasio area kerja di ruang dapur latih adalah $4 \mathrm{~m}^{2} /$ peserta didik, diskripsi kapasitas untuk 8 peserta didik. luas minimum adalah $32 \mathrm{~m}^{2}$. Lebar minimum adalah 4 m.”. Rombongan belajar di SMK jumlah siswa dalam satu kelas ratarata 32 orang. Oleh karena itu paling tidak luas ruang praktik dapur latih/dapur praktik adalah $64 \mathrm{~m}^{2}$, dengan asumsi satu tahap kegiatan praktik adalah separo jumlah siswa/kelas atau berjumlah 16 siswa.

Standar perabot dapur latih, dalam (Lampiran Permendiknas Nomor 40, Tahun
2008: p 145) di nyatakan bahwa "jenis perabot meliputi meja kerja, kursi/ stool, lemari simpan alat dan bahan dengan rasio 1 set/ruang dan minimum untuk 8 peserta didik pada pekerjaan dasar pembuatan berbagai macam makanan".

Standar peralatan dapur latih, (Sudira, 2004: pp 39-55) "peralatan dapur dibagi menjadi 2 (dua) yaitu peralatan kecil (utencil) dan peralatan besar (equipment).". Peralatan kecil (utencil) meliputi: (a) pot dan pan; (b) peralatan untuk menyimpan/ mencampur; (c) peralatan kecil; (d) peralatan memotong; (e) peralatan dari kayu; (e) peralatan dari karet; (f) peralatan dari plastik atau melamin. Peralatan besar (equipment) meliputi: (1) Peralatan listrik dan gas; (2) peralatan mekanik; (3) peralatan non listrik.

Pot dan pan berfungsi untuk memasak terdiri dari stock pot, sauce pot, sauce pan, saute pan, brising/rousting pan, frying pan; peralatan untuk menyimpan/mencampur: whisking bowl, mixing bowl, colander, container dan tray; peralatan kecil: ladle, skimer, spider, frying spatula, conical strainer, strainer, baloon whisk, ice cream scoop; peralatan memotong: peeler, small vegetable knife, vegetable knife, chopping knife, filleting knife, boning knife, bread knife, slicing knife, cleaver, sharpener, spatula, carving fork grater; peralatan dari kayu: chopping block, cutting board, wooden spatula, rolling pin; peralatan dari karet: rubber spatula; peralatan dari plastik atau melamin: cutting board, plastik bowl, plastik tray.

Peralatan besar (equipment) meliputi Peralatan listrik dan gas: egg boiler, toaster, deep fryer, tilting frying pan, bain marie, bakery oven, grill, stove dan oven, dough mixer, meat grinder, refrigerator, freezer; peralatan mekanik: hard meat grinder, nodle dough machine, timbangan; peralatan non listrik: table, shink, chopping block.

Berdasar fungsi peralatan dapur latih diklasifikasikan menjadi 3 (tiga). Pertama, peralatan persiapan (processing equipment). Peralatan ini digunakan dalam proses pengolahan makanan yang bersentuhan langsung dengan panas. Ada 3 jenis peralatan pelaksanaan memasak: (1) Alat pemanas. Alat ini digunakan untuk mematangkan bahan makanan karena diakibatkan oleh panas/api 
yang ditimbulkan pada alat tersebut. Misalnya: kompor, oven (pemanggang); (2) Alat bantu memasak diatas kompor (pemanas). Alat ini digunakan sebagai tempat bahan makanan yang proses pengolahannya dilakukan diatas api (kompor); (3) Alat bantu memasak didalam kompor (pemanas) atau oven. Alat ini digunakan sebagai tempat bahan makanan yang proses pengolahannya dilakukan didalam alat pemanas.

Kedua, peralatan pengolahan. Penyajian (serving equipment), alat ini digunakan untuk masakan (hidangan) yang telah melalui proses pemasakan (pengolahan) terlebih dahulu.

Ketiga, peralatan penyajian (serving equipment), alat ini digunakan untuk masakan (hidangan) yang telah melalui proses pemasakan (pengolahan) terlebih dahulu. Peralatan penyajian diantaranya : (1) China ware, alat ini digunakan sebagai (alat) tempat hidangan yang siap untuk dimakan; (2) Glass ware, alat ini digunakan sebagai alat (tempat) minum atau air; (3) Silver ware, alat ini digunakan sebagai alat makan.

Ruang Praktik Tata Hidang/ Melayani Makan dan Minum (Food and Beverage Service).

Ruang Praktik Tata Hidang adalah ruang untuk pembelajaran secara praktik yang dilengkapi perabot, peralatan makan dan peralatan penyajian makanan dan minuman. Ruang tersebut merupakan miniatur dari sebuah restoran yang ada di dunia usaha/dunia industri.

Standar Ruang Praktik Tata Hidang. Dalam (Lampiran Permendiknas Nomor 40, Tahun 2008: p 145) di nyatakan bahwa rasio area kerja di ruang praktik tata hidang adalah $16 \mathrm{~m}^{2} /$ peserta didik, Kapasitas untuk 8 peserta didik. Luas minimum adalah $128 \mathrm{~m}^{2}$. Lebar minimum adalah $8 \mathrm{~m}$. Rasio area kerja di ruang mini bar adalah $3 \mathrm{~m}^{2} /$ peserta didik, Diskripsi Kapasitas untuk 4 peserta didik. Luas minimum adalah $12 \mathrm{~m}^{2}$. Lebar minimum adalah $3 \mathrm{~m}$.

Standar perabot tata hidang, dalam (Lampiran Permendiknas Nomor 40, Tahun 2008: p 147) di nyatakan bahwa "jenis perabot meliputi meja kerja, kursi/ stool, lemari simpan alat dan bahan dengan rasio 1 set/ruang dan minimum untuk 8 peserta didik pada pekerjaan penataan hidangan dan untuk penyajian makanan".
Lampiran tentang daftar kebutuhan perabot ruang tata hidang pada buku pedoman analisis kebutuhan sarana pendidikan sekolah menengah kejuruan (SMK) bidang keahlian pariwisata, 2001 di sebutkan bahwa perabot yang diperlukan dalam kegiatan memasak meliputi: (1) Meja, Meja bulat (round table) diameter $100 \mathrm{~cm}$. dan atau meja persegi (square table) ukuran 100x100 cm., berfungsi untuk penataan meja makan; (2) kursi (Chair), berfungsi untuk duduk tamu di restoran; (3) Meja persediaan (Side board), berfungsi untuk lemari persediaan alat makan di restoran; Lemari alat kaca, berfungsi untuk menyimpan lenan dan alat jenis glass ware dan china ware.

Standar Peralatan Tata Hidang, peralatan Restoran dalam kegiatan pembelajaran praktik melayani makan dan minum lebih tepat dengan menggunakan istilah yang biasa dipakai di dunia usaha/dunia industri terutama di hotel yaitu dengan menggunakan istilah/bahasa Inggris. Hal tersebut perlu juga di terapkan dalam pembelajaran praktik disekolah untuk tujuan pencapaian kompetensi siswa.

Dalam (Brown, G., dan Hepner, K., 2000: pp 21-31) dijelaskan bahwa Food Service Equipment meliputi (1) Cutlery, basic (silverware) item; (2) Outher cutlery item sometimes placed on the table; (3) Cutlery item used for servin; (4) tableware; (5) large equipment".

\section{METODE PENELITIAN}

\section{Jenis penelitian}

Jenis penelitian ini adalah deskriptif kuantitaif. Metode kuantitatif di gunakan untuk mendiskripsikan data kelayakan sarana prasarana laboratorium yang meliputi (1) kelayakan ruang praktik dapur latih; (2) kelayakan ruang praktik tata hidang; (3) kelayakan perabot dapur latih; (4) kelayakan perabot tata hidang; (5) kelayakan peralatan dapur latih; (6) kelayakan peralatan tata hidang.

\section{Waktu dan Tempat Penelitian.}

Penelitian dilakukan di 7 (tujuh) SMK wilayah Mawitan, terdiri dari: (1) SMKN 4 Kota Madiun; (2) SMKN 1 Wonoasri Kabupaten Madiun; (3) SMKN 2 Magetan 
Kabupaten Magetan; (4) SMKN 1 Poncol Kabupaten Magetan; (5) SMKN Takeran Kabupaten Magetan; (6) SMKN Kartoharjo Kabupaten Magetan; (7) SMKN 1 Geneng, Kabupaten Ngawi.

Penelitian dilaksanakan mulai bulan Okotober 2013 sampai dengan 24 Juni 2014.

\section{Target/Subjek Penelitian.}

Subyek penelitian adalah SMK yang memiliki Program Studi Keahlian Tata Boga, Kompetensi Keahlian Jasa Boga yang ada di wilayah Kota Madiun dan Kabupaten Madiun, Kabupaten Ngawi, dan Kabupaten Magetan (Mawitan). Sumber data adalah laboratorium di SMK wilayah Mawitan.

\section{Teknik Pengumpulan Data}

Pengumpulan data dilakukan dengan teknik observasi menggunakan instrumen check list. Reliabilitas data hasil observasi dikendalikan dengan teknik interobserver yaitu melibatkan tiga orang observer dalam setiap proses pengumpulan data. Observer berasal dari guru produktif Jasa Boga yang telah berpengalaman mengajar teori dan praktik produktif minimal tiga tahun.

\section{Teknik Analisis Data.}

Analisis data pada penelitian ini menggunakan metode deskriptif kuantitatif. Analisis diskriptif kuantitatif digunakan untuk mendiskripsikan subyek penelitian yang diperoleh dari hasil observasi. Data tersebut digunakan sebagai landasan untuk mengungkap hasil penelitian..

Kriteria skor sarana prasarana laboratorium diperoleh dari hasil rerata skor dari total skor standar jumlah dan standar kondisi dibagi dua kali jumlah butir jenis/nama alat dengan ketelitian dua angka desimal. Adapun rumus untuk menentukan rerata skor adalah:

$$
\mathrm{A}=(\mathrm{A} 1+\mathrm{A} 2) / \mathrm{nx} 2
$$

Keterangan:

A : Bagian jenis/nama alat

$A_{1} \quad$ : Total skor standar jumlah

$\mathrm{A}_{2}$ : Total skor standar kondisi

$\mathrm{n} \quad$ : Jumlah butir jenis/nama alat
Kriteria skor sarana prasarana di sajikan seperti Tabel 1.

Tabel 1. Kriteria Skor Sarana Prasarana

\begin{tabular}{clc}
\hline No. & Jumlah & Skor \\
\hline 1 & Standar/lebih dari standar & 3 \\
2 & $\geq 1 / 2$ standar & 2 \\
3 & $<1 / 2$ standar & 1 \\
4 & Tidak ada/rusak & 0 \\
\hline
\end{tabular}

Hasil skor sarana prasarana dari tiga observer di jumlah. Total skor setiap bagian dari tiga observer minimal 0,00 dan maksimal 9,00. Perolehan skor tersebut menjadi dasar menentukan kriteria kelayakan sarana prasarana laboratorium jasa boga. Kriteria kelayakan laboratorium di kelompokkan ke dalam 4 (empat) kategori, seperti ditunjukkan pada Tabel 2 .

Tabel 2. Kriteria Kelayakan Sarana prasarana Laboratorium Jasa Boga

\begin{tabular}{ccc}
\hline No & Rentang Skor & Predikat \\
\hline 1 & $0,00-2,25$ & Tidak Layak \\
2 & $2,26-4,50$ & Belum layak \\
3 & $4,51-7,75$ & Layak \\
4 & $7,76-9,00$ & Sangat layak \\
\hline
\end{tabular}

\section{HASIL PENELITIAN DAN PEMBAHASAN}

\section{Rekapitulasi Hasil Observasi Ruang Praktik Dapur Latih di SMK Wilayah Mawitan.}

Berdasarkan Tabel 3, rata-rata dari jumlah dan kondisi Ruang Praktik Dapur latih/pengolahan makanan di SMKN 1 Poncol memiliki skor 8,50, predikat sangat layak. Ruang Praktik Dapur latih/pengolahan makanan di SMKN 2 Magetan memiliki skor 8,61 , predikat sangat layak. Ruang Praktik Dapur latih/pengolahan makanan di SMKN Takeran memliki skor 7,83, predikat sangat layak. SMKN Kartoharjo memiliki skor 8,83, predikat sangat layak. SMKN 1 Geneng memiliki skor 7,39, predikat layak. SMKN 1 Wonoasri adalah 8,83 , predikat sangat layak. SMKN 4 Madiun memiliki skor 9,00, predikat sangat layak. 
Tabel 3. Rekapitulasi Hasil Observasi Ruang Praktik Dapur latih/ pengolahan makanan

\begin{tabular}{clcc}
\hline No & Nama Sekolah & Skor & Keterangan \\
\hline 1 & SMKN 1 Poncol & 8,50 & Sangat Layak \\
2 & SMKN 2 Magetan & 8,61 & Sangat Layak \\
3 & SMKN Takeran & 7,83 & Sangat Layak \\
4 & SMKN Kartoharjo & 8,83 & Sangat Layak \\
5 & SMKN 1 Geneng & 7,39 & Layak \\
6 & SMKN 1 Wonoasri & 8,83 & Sangat Layak \\
7 & SMKN 4 Madiun & 9,00 & Sangat Layak \\
\hline
\end{tabular}

Tabel 4. Rekapitulasi Hasil Observasi Ruang Praktik Tata Hidang

\begin{tabular}{clcc}
\hline No & Nama Sekolah & Skor & Keterangan \\
\hline 1 & SMKN 1 Poncol & 0,00 & Tidak Layak \\
2 & SMKN 2 Magetan & 0,00 & Tidak Layak \\
3 & SMKN Takeran & 0,00 & Tidak Layak \\
4 & SMKNKartoharjo & 0,00 & Tidak Layak \\
5 & SMKN 1 Geneng & 8,21 & Sangat Layak \\
6 & SMKN 1 Wonosari & 8,36 & Sangat Layak \\
7 & SMKN 4 Madiun & 8,79 & Sangat Layak \\
\hline
\end{tabular}

Hasil Observasi Spesifikasi Ruang Praktik Dapur latih/pengolahan makanan adalah:

Area kerja, Luas dan lebar Ruang praktik Dapur latih/pengolahan makanan di seluruh SMK wilayah Mawitan sesuai standar spesifikasi, tetapi secara riil luas area kerja peserta didik semuanya belum sesuai dengan spesifikasi.

Kapasitas tiap ruang praktik, di SMK wilayah Mawitan belum ada yang sesuai standar spesifikasi yakni minimal 16 peserta didik/ ruang praktik. Data observasi menunjukkan SMKN 1 Poncol memiliki kapasitas 13 peserta didik, SMKN 2 Magetan 10 peserta didik, SMKN Takeran 6 peserta didik, SMKN Kartoharjo 12 peserta didik, SMKN 1 Geneng 8 peserta didik, SMKN 1 Wonoasri 7 peserta didik dan SMKN 4 madiun 10 peserta didik.

Lantai serta penerangan tiap ruang praktik semuanya sesuai dengan spesifikasi. Ventilasi ruang praktik dapur latih, SMKN Takeran memiliki ventilasi $<40 \%$ dan tidak ada exhause fan. Kelayakan Ruang Praktik Dapur Latih di SMK Wilayah Mawitan Jawa Timur, mayoritas sangat layak, sebagian layak dan sesuai standar spesifikasi Tetapi secara riil luas area kerja peserta didik semuanya belum sesuai dengan spesifikasi. Kapasitas ruang praktik di SMK Wilayah Mawitan sebenarnya memenuhi standar spesifikasi minimal.

Dari data yang tersaji dalam Tabel 3, enam dari tujuh sekolah berpredikat sangat layak dan satu sekolah berpredikat layak. Berarti 86\% SMK yang ada di wilayah Mawitan memiliki Ruang Praktik Dapur Latih sangat layak. Artinya SMK di wilayah Mawitan memiliki jumlah ruang praktik dapur latih yang mampu memenuhi keperluan kegiatan pembelajaran praktik yang kondisinya juga sesuai dengan persyaratan yang diperlukan.

Seperti dijelaskan oleh (Berte : 2007, p 780) sebelum peralatan dipilih, laboratorium perlu memverifikasi bahwa fasilitas fisik laboratorium dapat memenuhi kebutuhan peralatan untuk ruang dan beban bantalan, listrik, ventilasi, kelembaban, dan suhu; Jenis dan kelayakan air, dan persyaratan khusus lainnya.

Hygiene dan sanitasi lingkungan dapur sedapat mungkin dijaga kebersihannya, lingkungan dapur yang bersih dan sehat dapat memberikan keamanan dan kenyamanan kerja sehingga karyawan dapat bekerja dengan tenang, aman dan nyaman. 
Tabel 5. Rekapitulasi Hasil Observasi Perabot Dapur latih

\begin{tabular}{clcc}
\hline No & Nama Sekolah & Skor & Keterangan \\
\hline 1 & SMKN 1 Poncol & 8,68 & Sangat layak \\
2 & SMKN 2 Magetan & 8,23 & Sangat layak \\
3 & SMKN Takeran & 6,27 & Layak \\
4 & SMKN Kartoharjo & 9,00 & Sangat layak \\
5 & SMKN 1 Geneng & 8,23 & Sangat layak \\
6 & SMKN 1 Wonoasri & 8,23 & Sangat layak \\
7 & SMKN 4 Madiun & 8,59 & Sangat layak \\
\hline
\end{tabular}

\section{Rekapitulasi Hasil Observasi Ruang Praktik Tata Hidang di SMK Wilayah Mawitan.}

Tabel 4 menunjukkan, rata-rata jumlah dan kondisi Ruang Praktik Tata Hidang di SMKN 1Poncol, SMKN 2 Magetan, SMKN Takeran dan SMKN Kartoharjo memiliki skor 0,00, karena empat SMK tersebut belum memiliki prasarana ruang praktik Tata Hidang, predikat empat SMK tersebut tidak layak. SMKN 1 Geneng memiliki skor 8,21, predikat sangat layak. SMKN 1 Wonoasri memiliki skor 8,36 , predikat sangat layak. SMKN 4 Madiun memiliki skor 8,79, predikat sangat layak.

Hasil Observasi Spesifikasi Ruang Praktik Tata Hidang, Empat SMK belum memiliki prasarana praktik Tata Hidang yaitu SMKN 1 Poncol, SMKN 2 Magetan, SMKN Takeran dan SMKN Kartoharjo. Tiga SMK memiliki Ruang Praktik Tata Hidang yaitu SMKN 1 Geneng, SMKN 1 Wonoasri dan SMKN 4 Madiun.

Area kerja praktik setiap peserta didik sesuai spesifikasi. Kapasitas ruang praktik Tata Hidang minimal 16 peserta didik, di SMKN 1 Geneng berkapasitas 4 peserta didik, SMKN 1 Wonoasri berkapasitas 4 peserta didik dan di SMKN 4 Madiun, berkapasitas 6 peserta didik.

Luas ruang praktik Tata Hidang di 7 SMK wilayah Mawitan belum sesuai spesifikasi, karena kurang dari $128 \mathrm{~m}^{2}$.

Lebar ruang Tata Hidang minimal $8 \mathrm{~m}$, yang memenuhi syarat baru SMKN 4 Madiun dan SMKN 1 Geneng.

Lantai, Ventilasi dan Drainase, di 7 SMK wilayah Mawitan sesuai spesifikasi.

Memperhatikan data yang tersaji dalam tabel 4, tiga dari tujuh sekolah berpredikat sangat layak. Berarti 43\% SMK di wilayah
Mawitan memiliki Ruang Praktik Tata Hidang sangat layak. Empat sekolah (57\%) berpredikat tidak layak. Karena empat sekolah tersebut memang belum memiliki Ruang Praktik Tata Hidang.

Hasil Observasi Spesifikasi Ruang Praktik Tata Hidang adalah: (a) Terdapat empat SMK yang belum memiliki prasarana praktik Tata Hidang yaitu SMKN 1 Poncol, SMKN 2 Magetan, SMKN Takeran dan SMKN Kartoharjo. Kemudian tiga SMK yang memiliki Ruang Praktik Tata Hidang yaitu SMKN 1 Geneng, SMKN 1 Wonoasri dan SMKN 4 Madiun; (b) Area kerja praktik setiap peserta didik sesuai spesifikasi, tetapi kapasitas ruang praktik Tata Hidang di SMKN 1 Geneng, SMKN 1 Wonoasri dan SMKN 4 Madiun, masing-masing baru berjumlah 4 peserta didik dan untuk SMKN 4 Madiun berjumlah 6 peserta didik; (b) Luas ruang praktik Tata Hidang belum sesuai spesifikasi, karena kurang dari $128 \mathrm{~m}^{2}$. Lebar ruang Tata Hidang yang memenuhi syarat baru SMKN 4 Madiun dan SMKN 1 Geneng; (c) Lantai, Ventilasi dan Drainase semuanya sesuai spesifikasi.

\section{Rekapitulasi Hasil Observasi Perabot Dapur latih di SMK Wilayah Mawitan.}

Data pada Tabel 5 menunjukkan bahwa Sarana Perabot Dapur latih di SMKN 1 Poncol memiliki skor 8,68, predikat sangat layak. SMKN 2 Magetan memiliki skor 8,23, predikat sangat layak. SMKN Takeran memiliki skor 6,27, predikat layak. SMKN Kartoharjo memiliki skor 9,00, predikat sangat layak. SMKN 1 Geneng memiliki skor 8,23, predikat sangat layak. SMKN 1 Wonoasri memiliki skor 8,23 , predikat sangat layak. SMKN 4 Madiun memiliki skor 8,59 dan predikat sangat layak. 
Tabel 6. Rata-rata Skor Peralatan Dapur Latih

\begin{tabular}{clcc}
\hline No & Nama Sekolah & Skor & Keterangan \\
\hline 1 & SMKN 1 Poncol & 7,37 & Layak \\
2 & SMKN 2 Magetan & 8,48 & Sangat layak \\
3 & SMKN Takeran & 7,11 & Layak \\
4 & SMKN Kartoharjo & 8,00 & Sangat layak \\
5 & SMKN 1 Geneng & 8,05 & Sangat layak \\
6 & SMKN 1 Wonoasri & 8,31 & Sangat layak \\
7 & SMKN 4 Madiun & 7,84 & Sangat layak \\
\hline
\end{tabular}

Hasil Observasi Spesifikasi Perabot dan Peralatan Lain di Dapur Latih adalah: (a) Meja kerja, di SMKN Takeran tidak sesuai standar spesifikasi, karena berbahan kayu. Di SMKN 1 Poncol, Kartoharjo, SMKN 1 Geneng dan SMKN 1 Wonoasri meja kerja berasal dari bahan keramik. SMKN 2 Magetan dan SMKN 4 Madiun sesuai standar spesifikasi yaitu Stainleessteel, ukuran: $60 \mathrm{~cm} . x 120 \mathrm{~cm} ., \mathrm{T}$ : 180 cm; (b) Almari alat (bawah meja kerja), SMKN 2 Magetan, SMKN Takeran dan SMKN 1 Wonoasri belum ada, tetapi memungkinkan untuk di buat SMKN 1 Poncol, SMKN 2 Magetan dan SMKN 4 Madiun ada, tetapi dalam keadaan terbuka, tidak dimanfaatkan sebagaimana fungsinya; (c) Bak cuci, Almari bahan, Almari bumbu, Kotak Kontak/saklar, Tempat sampah, Sapu Cikrak (Jw. cikrak), Alat pel, Pemadam api (extinguisher), di 7 SMK wilayah mawitan semua sesuai standar spesifikasi.

Berdasarkan deskripsi data yang ada pada tabel 5, enam dari tujuh sekolah berpredikat sangat layak dan satu sekolah berpredikat layak. Berarti $86 \%$ SMK yang ada di wilayah Mawitan memiliki Perabot Dapur Latih sangat layak. Artinya SMK di wilayah Mawitan memiliki jumlah perabot dapur latih yang sesuai standar. sehingga mampu memenuhi keperluan kegiatan pembelajaran praktik yang kondisinya juga sesuai dengan persyaratan yang diperlukan.

\section{Rekapitulasi Hasil Observasi Peralatan Dapur Latih di SMK Wilayah Mawitan.}

Tabel 6 menyajikan data Rata-rata skor Peralatan Dapur Latih. Dari tiga jenis peralatan praktik dapur latih yaitu peralatan persiapan, peralatan pengolahan dan peralatan penghidangan dihasilkan rerata sebagai berikut: dua sekolah (29\%) berpredikat layak, lima SMK (71\%) berpredikat sangat layak. Berarti SMK yang ada di wilayah Mawitan memiliki Peralatan Dapur Latih sangat layak. Artinya SMK di wilayah Mawitan memiliki jumlah peralatan dapur latih yang sesuai standar sehingga mampu memenuhi keperluan kegiatan pembelajaran praktik yang kondisinya juga sesuai dengan persyaratan yang diperlukan.

Hasil observasi spesifikasi peralatan penghidangan. Dari 9 macam peralatan penghidangan yang harus tersedia, enam sekolah (86\%) yaitu SMKN 1 Poncol, SMKN 2 Magetan, SMKN Kartoharjo, SMKN 1 Geneng, SMKN 1 Wonoasri dan SMKN 4 Madiun semua tersedia. Tetapi umumnya keberadaan peralatan penghidangan masih menjadi satu dengan fasilitas peralatan praktik di ruang Tata Hidang khususnya SMKN 4 Madiun, sedangkan di enam sekolah lainnya peralatan penghidangan berada di ruang praktik dapur latih.

Untuk SMKN Takeran belum memiliki fasilitas peralatan penghidangan jenis Dinner plate, Dessert plate, Soup Cup and saucer, Bowl, dan Cocktil Glass.

\section{Rekapitulasi Hasil Observasi Perabot Tata Hidang di SMK Wilayah Mawitan.}

Pada Tabel 7 disajikan data hasil observasi Perabot Tata hidang. SMKN 1 Poncol memperoleh skor 0,82 , predikat tidak layak. SMKN 2 Magetan memiliki skor 6,75, predikat layak. SMKN Takeran memiliki skor 0,00, predikta tidak layak. SMKN Kartoharjo memiliki skor 6,00, predikat layak. SMKN 1 Geneng mendapat skor 6,75 , predikat layak. 
Tabel 7. Rekapitulasi Hasil Observasi Perabot Tata hidang

\begin{tabular}{clcc}
\hline No & Nama Sekolah & Skor & Keterangan \\
\hline 1 & SMKN 1 Poncol & 0,82 & Tidak layak \\
2 & SMKN 2 Magetan & 6,75 & Layak \\
3 & SMKN Takeran & 0,00 & Tidak layak \\
4 & SMKN Kartoharjo & 6,00 & Layak \\
5 & SMKN 1 Geneng & 6,75 & Layak \\
6 & SMKN 1 Wonoasri & 6,00 & Layak \\
7 & SMKN 4 Madiun & 8,00 & Sangat layak \\
\hline
\end{tabular}

Tabel 8. Rata-rata Skor Peralatan Tata Hidang

\begin{tabular}{clcc}
\hline No & Nama Sekolah & Skor & Keterangan \\
\hline 1 & SMKN 1 Poncol & 5,48 & Layak \\
2 & SMKN 2 Magetan & 6,38 & Layak \\
3 & SMKN Takeran & 0,27 & Tidak layak \\
4 & SMKN Kartoharjo & 5,26 & Layak \\
5 & SMKN 1 Geneng & 5,26 & Layak \\
6 & SMKN 1 Wonoasri & 7,59 & Sangat Layak \\
7 & SMKN 4 Madiun & 8,79 & Sangat Layak \\
\hline
\end{tabular}

SMKN 1 Wonoasri memiliki skor 6,00, predikat layak, SMKN 4 Madiun memiliki skor 8,00 , predikat sangat layak.

Hasil Observasi Spesifikasi Sarana Tata Hidang. SMKN 1 Poncol dan SMKN Takeran belum memiliki sarana Tata Hidang. Sedangakan untuk SMKN 2 Magetan, SMKN Kartoharjo, SMKN 1 Geneng, SMKN 1 Wonoasri dan SMKN 4 Madiun memiliki sarana/perabot Tata Hidang sesuai spesifikasi.

Berdasarkan Tabel 7, hasil observasi Perabot Tata Hidang, terdapat dua sekolah yang berpredikat tidak layak (29\%), kemudian sekolah yang berpredikat layak berjumlah empat (57\%) sedangkan satu sekolah berpredikat sangat layak (14\%). Sekolah yang berpredikat tidak layak karena memang belum memiliki perabot Tata hidang.

Hasil Observasi Spesifikasi Sarana Tata Hidang. SMKN 1 Poncol dan SMKN Takeran belum memiliki sarana/perabot Tata Hidang. Sedangkan untuk SMKN 2 Magetan, SMKN Kartoharjo, SMKN 1 Geneng, SMKN 1 Wonoasri dan SMKN 4 Madiun memiliki sarana/perabot Tata Hidang yang sesuai spesifikasi.

\section{Rekapitulasi Hasil Observasi Peralatan Tata Hidang di SMK Wilayah Mawitan.}

Hasil Observasi Rata-rata Skor Peralatan Tata Hidang (Furniture, Lena, China ware, Glass, Silver ware, Accessories, Mocktail dan Other Equipment) menunjukkan bahwa dari tujuh SMK di wilayah Mawitan:

Satu sekolah berpredikat tidak layak dengan memiliki rerata skor 0,27. Empat sekolah berpredikat layak. Dua sekolah berpredikat sangat layak.

\section{SIMPULAN DAN SARAN}

\section{Simpulan}

Ruang Praktik Dapur Latih di SMK Wilayah Mawitan Jawa Timur, semua sesuai standar spesifikasi dan mayoritas sangat layak (86\%).

Ruang Praktik Tata Hidang dari tujuh sekolah baru tiga sekolah (47\%) yang memiliki ruang praktik Tata Hidang, empat sekolah $(53 \%)$ belum memiliki ruang praktik Tata Hidang. Ruang Praktik Tata Hidang sangat layak, tetapi memiliki luas ruang praktik di bawah standar. 
Perabot dapur latih di SMK wilayah Mawitan Jawa Timur, 86\% memiliki Perabot Dapur Latih sangat layak. Artinya SMK di wilayah Mawitan memiliki jumlah perabot dapur latih yang sesuai standar sehingga mampu memenuhi keperluan kegiatan pembelajaran praktik yang kondisinya juga sesuai dengan persyaratan yang diperlukan.

Peralatan Dapur Latih di SMK Wilayah Mawitan Jawa Timur, 57\% memiliki Peralatan Dapur Latih sangat layak. Artinya memiliki jumlah peralatan dapur latih yang sesuai standar sehingga mampu memenuhi keperluan kegiatan pembelajaran praktik yang kondisinya juga sesuai dengan persyaratan yang diperlukan. 29\% memiliki Kelayakan Peralatan Dapur Latih layak dan 14\% memiliki kelayakan tidak layak.

Perabot Tata Hidang di SMK wilayah Mawitan Jawa Timur, 29\% tidak layak, 57\% layak dan 14\% sangat layak.

Peralatan Tata Hidang di SMK wilayah Mawitan Jawa Timur,14\% tidak layak, 57\% layak, 29\% sangat layak.

\section{Saran}

Prasarana ruang praktik dapur latih yang ada di SMK wilayah Mawitan memiliki luas yang memenuhi standar, tetapi secara riil luas area kerja belum sesuai standar oleh karena itu perlu dilakukan pembenahan khususnya pada rasio area kerja. Untuk melakukan pembenahan dapat mengacu pada "Tabel 3.41.1 Jenis, Rasio, dan Deskripsi Standar Prasarana Ruang Praktik Program Keahlian Restoran (Lampiran Permendiknas Nomor 40, Tahun 2008:145)".

Meja kerja ada yang tidak sesuai standar spesifikasi, almari bawah meja perlu optimalisasi sesuai fungsi dan kondisi. Sebaiknya meja kerja secara bertahap dilakukan pembenahan terutama meja kerja yang berasal dari kayu/papan yang relatif empuk/lunak sebaiknya secara bertahap di ganti dengan meja stainlesssteel.

Almari bawah meja perlu optimalisasi sesuai fungsi dan kondisi, sebaiknya di lengkapi pintu agar peralatan persiapan dan peralatan pengolahan yang di simpan di almari tersebut tidak mudah dinjangkau serangga kondisi area kerja menjadi baik, bersih dan rapi.
SMK yang belum memiliki peralatan penghidangan atau peralatan penghidangan dapur latih masih menjadi satu dengan peralatan praktik Tata Hidang, sebaiknya di pisahkan tersendiri untuk memperlancar kegiatan praktik peserta didik.

Lebar Ruang Tata Hidang ada yang belum memenuhi syarat. Untuk itu bagi Sekolah yang ketepatan belum memiliki ruang praktik Tata Hidang jika akan membangun dianjurkan mengacu pada Lampiran Permendiknas Nomor 40, Tahun 2008 tentang Standar Sarana dan Prasarana untuk Sekolah Menengah Kejuruan/ Madrasah Aliyah Kejuruan (SMK/MAK).

Secara umum sarana fasilitas peralatan dan kondisi sesuai standar bahkan jumlahnya melebih dari standar jumlah, tetapi di sisi lain justru ada jenis alat yang belum ada, untuk itu peralatan yang belum ada tersebut diharapkan menjadi skala prioritas dalam penyusunan program pengadaan peralatan.

Sesuai buku pedoman analisis kebutuhan sarana pendidikan sekolah menengah kejuruan (SMK) bidang keahlian pariwisata, bahwa kebutuhan peralatan praktik adalah separo dari jumlah rombongan belajar. Standar peralatan praktik tata hidang ditentukan cukup untuk 4 kelompok, setiap kelompok 4 peserta didik (1 peseta didik sebagai pramusaji, 3 peserta didik sebagai tamu) sehingga sekali praktik bisa menampung separo jumlah rombongan belajar (16 peserta didik).

\section{DAFTAR PUSTAKA}

Berte, Lucia M. MA, MT(ASCP)SBB, DLM, CQA(ASQ)CQM/OE (2007). Laboratory Quality Management: A Roadmap. Clin Lab Med 27 (2007) 771-790. Di ambil pada tanggal 7 Desember 2013, dari http://www. okyanusbilgiambari.com/bilgiambari/ Yalin/Yalin.Giris/Roadmap-LQM. Laboratuvar.pdf

Brown, G., dan Hepner, K. (2000). The Waitre's Handbook. Australia: Southwood Press Pty Ltd., Frankston, Victoria.

Depdiknas. (2005). Peraturan Pemerintah RI Nomor 19, Tahun 2005, tentang Standar Nasional Pendidikan 
Depdiknas. (2006). Lampiran Permendiknas Nomor 23, Tahun 2006, tentang Standar Kompetensi Lulusan (SKL)

Depdiknas. (2008). Lampiran Permendiknas Nomor 40, Tahun 2008, tentang Standar Sarana dan Prasarana untuk Sekolah Menengah Kejuruan/Madrasah Aliyah Kejuruan (SMK/MAK)

Depdiknas. (2008). Permendiknas Nomor 40, Tahun 2008, tentang Standar Sarana dan Prasarana untuk SekolahMenengah Kejuruan/ Madrasah Aliyah Kejuruan (SMK/MAK)

Diretorat Jendral Pendidikan Dasar dan Menengah Direkrotat Pendidikan Menengah Kejuruan. (2001). Pedoman Analisis Kebutuhan Sarana Pendidikan SMK Bidang Keahlian Pariwisata. Jakarta: Departemen Pendidikan Nasional.
Tim Penyusun. (2007). Kamus Besar Bahasa Indonesia. Kamus Pusat Bahasa, edisi 3, cetakan 3. Jakarta: Balai Pustaka.

Pavlova, M. (2009). Technology and Vocational Education Empowering Individuals for the Future. Australia: Griffith University, QLD.

Putu Sudira, B.. (1994). Tata Boga. Jakarta: Depdikbud Dirjen Dikdasmen Direktur Pendidikan Menengah Kejuruan.

Rahayuningsih,E. dan Dwiyanto, D. (2005). Pembelajaran Di Laboratorium. Yogyakarta: Pusat Pengembangan Pendidikan Universitas Gadjah Mada Yogyakarta.

Sudira, P. (2012). Filisofi \& Teori Pendidikan Vokasi dan Kejuruan. Yogyakarta: UNY Press. 